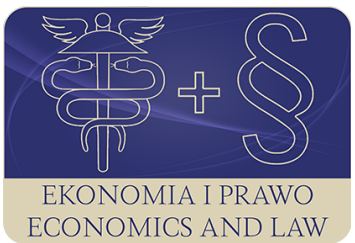

EKONOMIA I PRAWO. ECONOMICS AND LAW

Volume 20, Issue 1, March 2021

p-ISSN 1898-2255, e-ISSN 2392-1625

www.economicsandlaw.pl

EKONOMIA I PRAWO
ECONOMICS AND LAW

ORIGINAL ARTICLE

received 30.03.2019; revised 07.04.2020; accepted 31.03.2021

Citation: Ślęzak, E., \& Mamcarczyk, M. (2021). Globalisation and gender aspects of professional sport: the case of Poland. Ekonomia i Prawo. Economics and Law, 20(1): 173-189. doi:10.12775/EiP.2021.011.

\title{
Globalisation and gender aspects of professional sport: the case of Poland
}

\author{
EWA ŚLĘZAK \\ corresponding author \\ Cracow University of Economics, College of Economics, Finance and Law, Institute of Economics, \\ Department of Economics, ul. Rakowicka 27, 31-510 Kraków, Poland \\ 曰slezake@uek.krakow.pl \\ (D) orcid.org/0000-0002-8258-7786
}

\section{MARIOLA MAMCARCZYK}

Cracow University of Economics, College of Economics, Finance and Law, Institute of Economics, Department of Economics, Poland

๑mamcarcm@uek.krakow.pl

(D) orcid.org/0000-0003-0316-533X

\begin{abstract}
Motivation: Globalisation is not only about the mobility of capital and proliferation of global problems. It is also about common approaches in public governance. Modern technologies help to disseminate information on sport as well as raise interests and encourage citizens to engage in sport. Globalisation has made it easier. There is no need to travel - Olympic Games, football matches and various other sports can be watched on TV, with broadcasts offering more insights than live watching on the spot. Globalisation, however, is also seen in various public or grass-root initiatives which, by addressing existing inequalities, support certain groups i.e. women or minorities to help them achieve more equal position in sport.

Aim: The paper's aim is to analyse the impact of globalisation (use of modern, digital technologies) on public governance in sport based on the example of Poland. Poland is specific because there exists a strong gender bias and unequal involvement of men and women in professional sport. It translates into financial support. All of the above aspects will be scrutinized.

Results: The analyses will be based on the available public data on the financing of professional sport as well as achievements in the Olympic Games between the years 1924
\end{abstract}


and 2016. Moreover, some light will be shed on media coverage of sports events. The applied research methods include a critical literature review and analyses of gathered statistical data. The paper fills in the gap in the existing literature where impact of globalisation on sport in terms of public governance and gender imbalance is not often discussed.

Keywords: globalisation; gender; professional sport; sports achievements JEL: F6; Z20; Z23; Z28

\section{Introduction}

There is no doubt that sport is a multidimensional phenomenon that influences individuals and their welfare. The decision and policy makers are aware of the fact that sport is seen as a source of national identity and potential pride of citizens. Sport is also seen as a way to share common values which unite supporters across the globe. As a result, policy makers happily organise competitions, or similarly to the international trade processes, they make decisions to finance selected disciplines which allows countries to 'specialise' in given successful disciplines. Individual national approaches to sport and support of sports individuals vary, still the core is the fact that physical activity keeps people fit, but also makes them compete and adhere to existing rules of behaviour (Rischka-Stowik, 2014, p. 27). Obviously, physical activity and the will to compete are pivotal to sport as a category. They are combined with other rules, which inter alia include fair play — obligatory to all sports-related actors, such as players, organisers, but also supporters.

Globalisation affects sport and sportspersons as almost all countries across the globe are involved in sport. It is visible at the start of Olympic Games when sportsmen and sportswomen are entering the Olympic venue, or during the award ceremonies, when they show their pride in national flags and anthems. Moreover, modern technologies via medialisation and virtualisation increase access to sport, streaming and spreading the news, affecting the economy, society, culture and politics, which seem to synchronise (Cohen \& Kennedy, 2007).

The motives behind attempts to explore this theme relate to authoresses interests in globalisation as such, and the fact that sport does not seem to be sufficiently analysed in the globalisation discourse, especially in terms of more and less privileged groups and existing disparities, i.e. women or minorities.

The paper aims at analysing the impact of globalisation on policy making in the area of professional sport in Poland showing some gender imbalance. The issues of gender in professional sport, financial support and achievements will be scrutinised and juxtaposed to globalisation discourse.

The analyses are based on the available, fairly recent data on financing sport and Olympic Games achievements in the years 1924-2016. Moreover, taken the technological developments, the media coverage of sport will also be commented on. The applied research methods include critical literature review and analyses of gathered statistical data. The literature review is interdisciplinary and it is set in the global political economy, in particular the radical 
discourse, globalisation and modern technologies, as well as sociology and management of sport. The statistics and financial data related to Olympic Games allow to draw some cautious conclusions on gender imbalance in sport. The initial research question is whether the key axis dividing professional sport in Poland is gender related, and whether globalisation has an impact on professional sport both in its digital and technological aspects.

The paper is meant to fill in the existing gap in the literature on global political economy, economics, sociology and management studies. It ends with conclusions regarding gender, financing, achievements and the role played by globalisation and modern technologies in professional sport. The discussion presents a very modest statistical analysis of achievements at Olympic Games. The authoresses will offer some conclusions also pointing to new areas for further research.

\section{Literature review}

The literature on sport points to its social function (Cynarski et al., 2012; Doktór, 2005; Jakubowska \& Nosal, 2017; Lenartowicz \& Mosz, 2018; Nowocień \& Chełmecki, 2010), as well as its institutional perspective and embeddedness in specific management systems (Bednarczyk \& Batorski, 2009; Pastwa, 2000; Pawlak \& Smoleń, 2007; Waśkowski \& Sojkin, 2011; Żyśko, 2008). The discourse does not focus on sport per se but rather shows it in connection to globalisation (Dziubiński \& Rymarczyk, 2010; Polus, 2009; Sporek, 2007; Sznajder, 2017). It addresses selected disciplines in various age context (Wicker et al., 2009), or looks at sport as part of the school curricula (Nowocien, 2001). Much of the discussion is set in the European context and supranational policy recommendations are spelled out (Foks, 2006).

The present rise of interest in sport stems from the fact that recent centuries have been characterised by a significant growth of sport and its social role. The latter is attributed to globalisation and wider access to information thanks to the development of modern and digital technologies, as well as the change in lifestyles in high and middle income countries. Similar patterns appear in lower income countries as they try to catch up, however, the changes are not as common as in richer countries where sport in various forms is more accessible and is part of a daily life routine. It is worth to note that, in general, sport may be seen in a given socio-cultural context as both passive and active. Sport's passive roles relate to watching, analysing or supporting individuals, while active roles refer to practising sport, either professionally or as a hobby. Both roles are strongly connected with individual class affiliation, wealth and background. However, due to access to modern, digital technologies, this affiliation is more visible when it comes to active roles and engagement in a given discipline.

Professional sport is also an area of public governance. The ministries in charge of sport analyse the impact of given disciplines on the economy and make decisions such as organisation of international competitions and games or popu- 
larisation of certain sport via public television channels. Surely, this is the area that requires more attention as budgets spent on sportspersons, training bases and schemes vary. Some countries have consistent strategies and policies, some follow supranational solutions, finally some do nothing to help young sports talents. Some only decide to effectively prepare to take part in games and competitions. It is also worth to note that those in charge of the national identity use sport in a narrative to evoke pride in being a citizen of a given country.

No doubt various factors influence the shape and direction of sport-related policies. These are budgetary constraints, interests and awareness of the policy makers, as well as the role of sport in the policy context. In some cases, the emphasis is put on sport and competition, set in the school curricula, that support healthy lifestyles and might have a positive impact on the individual to choose a sports career.

In addition to the above, grass root initiatives should be noted, such as non-governmental and charity activities. In some cases, professional sport could be regarded as a way to help individuals out of poverty traps.

The policy making in sport is implemented through digital technologies as, due to the present wave of globalisation, they are present in almost every form of human activity. Furthermore, minimisation of devices and the increase in their capabilities allow individuals to be constantly connected and informed. Various devices provide their owners with information about their favourite celebrities, results of games etc. There is no need to travel thousands of kilometres. Supporters can receive constant updates and be involved without significant consequences for their professional or family lives. Media and modern technologies are conducive to building a sense of community and connectivity that develops around the idea of sport. In addition, modern technologies are now a part of sports processes helping to check the correctness of achieved results in case of any doubts.

The policy makers are aware of the growing role of technologies in human lives. As a result, governments and associations, both national and international, adopt policies and strategies which are widely available due to modern technologies, in particular the Internet. Politicians and policy makers are actively lobbying when countries seek to organise mass sport events, i.e. Olympic Games and world championships. For many countries sport has become the space for building international position of an attractive venue for international events. They usually express their will to host these events and to attract various actors. It can be compared to encouraging foreign capital to invest (Hay, 2011).

Furthermore, political globalisation is associated with the economic dimension given the organisation of major sporting events of international importance. It generates not only expenses related to investments, but also results in new jobs and increased tourism.

Last but not the least is the socio-cultural dimension of globalisation in sport. Sport is an element of social landscape, uniting people of different origins, class, race, ethnicity and orientation. Numerous interactions as well as flows associ- 
ated with them can be observed. Contemporary sport has become an element of culture, filled with flows of images, metaphors, and other abstract forms of the social and cultural space (Ślęzak, 2018, p. 33). As a result, while some present meanings change, additional forms are created and all of these synthesize within the framework of creolisation (Hannerz, 2000).

Moreover, sport supports integration and inclusion of individuals - with and without disabilities - to the mainstream society. Surely, participation in sport, as well as participation in international events, is set in a context of social networks and is inherent to local conditions. The desire to compete creates links between individuals, often pointed to as a form of social capital. Grodecki (2018) points to the fact that practising sport is an asset, however, sport practised in a group brings additional gains - people training in teams bond and tend to respect rules.

This area seems to be already full of various interactions, also between men and women. Sport is, however, not an equal space for them as they compete separately. Some disciplines, such as ski jumping, are mainly male represented, while others, like athletics, are practised by men and women alike. Moreover, some disciplines are gaining interest among women and, as a result, they receive international recognition as a professional sport, e.g. football, boxing. The separation of men and women in sport or domination of one gender have consequences in unequal financing, interest and performance.

Olympic Games, both current and those from the past, can be used as an example of a global sport phenomena based on the ideas of Baron Pierre de Coubertin. It is the arena for a fair competition among sportspersons, where supporters can cheer them up, whether in real or virtual world. This is happening despite the existence of various obstacles, such as financial, political, cultural or ecological. Therefore, Games can be used as a basis for exemplifications and analyses, not only in the context of a globalisation-induced phenomenon, but also in a gender context which has not yet been raised in the literature much, though the subject of inequality is widely discussed by various authors (Dirzyte et al., 2017; Roemer, 2011).

\section{Methods}

The applied research methods include a critical review of literature on sport and globalisation, the relation that is not widely discussed in literature. Additionally, gender and policy perspectives in sport are introduced. Then, some analyses of gathered statistical data are presented. The analysis starts with sports expenditure and then passes to achievements and gender differentiation.

General information on sport financing shows the attitude of the state and policy makers towards sport. The statistics present central budget expenditure on physical education and professional sport. The data also address regulatory changes, such as amended nomenclature in various acts. 
Some obstacles emerged in case of data available in the Public Information Bulletin provided by the Polish Ministry of Sport and Tourism. Some data turns out to be inconsistent and it is not possible to unequivocally state the amounts allocated to various contests, Olympic Games and the disciplines. The data is presented in various forms which are not full and coherent, and thus they are incomparable across decades. As a result, the expenditure was analysed based on the data from the years 2009 to 2019.

The expenditure analysis serves as a starting point for further research. Taken the fact that various games and championships are organised in particular disciplines or sets of a discipline, like skiing or athletics, the wider approach to Olympic Games was adopted. Olympic Games gather various disciplines which are listed as typical for summer or winter, depending of the edition of games. As Winter Olympics are more male-orientated and not as versatile as summer games, the analyses focused on the achievements of the summer Olympic Games. They cover the period between 1924 and 2016 and are complemented with graphic presentation of data.

\section{Results}

Sport in Poland, as in other developed countries, is part of the public governance. The national policies work on their own but they are also complemented with the European sport-related policy making. In fact, since the ratification of the Treaty of Lisbon (2007) sport has become one of the key areas of the EU activity. Sport is not regarded purely as a physical activity influencing condition of the EU citizens, but as an educational tool supporting social integration and cohesion of the European Union. Such an approach allows for financing sports infrastructure in member states (Mamcarczyk, 2016, pp. 181-186). Article 6 of the Treaty on the functioning of the European Union (2012) states that the European Union has the competence to carry out activities aimed at supporting, coordinating or supplementing the member states' activities. One of the areas of such activities at the European level is education, vocational training, youth and sport. As a result, the Council of the European Union agreed on Recommendation on promoting health-enhancing physical activity across sectors (2013). In Poland, similarly to other member states, the level of physical activity varies. As for the other countries, some continue to encourage citizens to increase their physical activity, while others lag behind the recommended levels. It obviously affects areas such as sport and health. Therefore, an increase in the level of physical activity along with strategic cross-sectoral approach is needed to promote health-related physical activity, and it should include involvement of all relevant ministries, bodies and organisations at all levels, in particular sports movements (Council Recommendation, 2013). This indicates the present position of sport in the policy agenda of the EU, which is additionally complemented with the number of policy documents addressing sport-related issues. 
The policy framework of the Polish government is also full of various actions aimed at stimulating physical activity. The changes in sport policies of Poland were reinforced with the European Union accession. In fact, the social and economic dimension of sport were themes of the Polish Presidency of the EU, when counteracting social exclusion and the significant impact of sport on the economy were highlighted. The actions of the Polish Presidency were in line with the Europe 2020 strategy and the Communication of the European Commission Developing the European dimension of sport (Ministry of Foreign Affairs, 2011). Moreover, these policies were enriched with the possibility to carry out big sports events such as the European Men Basketball Championships 2009, the European Women Volleyball Championships 2009, the World Rowing Championships 2009, the European Football Championships EURO 2012 (together with Ukraine).

Regular sport activity remains the priority for the national policy makers as it affects health and mental well-being of citizens, not to mention their fitness. The focus is on recreational sport as more and more pupils in Polish schools tend to avoid physical education classes. Thus the policy makers place more emphasis to promote it, and there are numerous programmes such as: (1) the general swimming programme in Poland I can swim; (2) The little master project; (3) the campaign Stop exemptions from PE classes.

Sport policies remain linked to health policies, which is clearly seen in the National Health Programme for the years 2007-2015 that complements the Strategy for the development of health care in Poland for 2007-2013. The operational goal 4 sets the need to increase the physical activity of the population since only ca. $30 \%$ of children and adolescents, and as few as $10 \%$ of adults practice sports to meet the body needs (Resolution of the Council of Ministers regarding the National Health Program for 2007-2015, 2007). The subsequent Programme for the years 2016-2020 emphasises diet and nutrition improvement, as well as physical activity of the society (Regulation of the Council of Ministers regarding the National Health Program for 2016-2020, 2016).

Apart from the above mentioned policies there are programmes for the development of small-scale sports and recreation infrastructure of a multi-generational character - Open Activity Zones (OSA). It is a response to the research showing that multifunctional activity zones are at the forefront of the most desirable forms of sports and recreation infrastructure. In the years 2018-2019 as many as 2,950 facilities were co-financed, costing nearly PLN 105 million (Ministry of Sport and Tourism, 2019).

Finally, the 2020 Sports development programme published by the Ministry of Sport and Tourism (2015) defines strategic goals, priorities and directions of intervention. Particularly interesting are 4 specific objectives which are: (1) provision of conditions for universal physical activity at every stage of life; (2) use of sport to build social capital; (3) improving the organisational and legal conditions for the development of sport and increasing the availability of qualified human resources; (4) exploiting the potential of sport at the competitive 
level for dissemination of physical activity, or promotion of Poland on the international arena.

Moving down from policy making to the national spending it can be noticed that budgets on sport are an element of physical culture including sport, physical education and physical resilience (Act on sport, 2010). Thus, related expenditure refers to competitive and general sport (e.g. programmes promoting physical activity in society, but also co-financing investments in sports facilities). Recreational sport is seen as a mass public activity, a form of active leisure and rest. Finally, qualified sport is regarded as an activity focusing on achieving best possible results, e.g. world records (PWN, 2019) (scheme 1). Such an approach formulates a framework, which in fact is not rigid - a given person can be a young football player who rides a bicycle for recreational purposes (Mamcarczyk, 2018).

It is interesting to note that the share of expenses in total budget expenditure is below $1 \%$. It varies between mere $0.06 \%$ and $0.31 \%$. The only period with more generous public spending were the years 2008-2012, especially 2011 when it increased to $0.31 \%$. This could be, however, explained by preparations for the summer Olympic Games 2012 (table 1).

The expenditure on professional sport (table 2) include preparations for Olympic Games, Paralympic Games, the Games of the Deaf, Championships and European Championships. In some years the expenditure from the central budget exceed the amounts allocated to physical culture at large. However, in the period of excessive spending on physical culture, there was a substantial decrease in professional sport spending. This is of course a subject for some concern, as total amounts, both budgeted and actual, imply that sport is not the priority for policy makers, thus this issue requires future attention.

Public expenditure on sport, whether physical culture or professional sport, is merely a starting point for discussion on financing and achievements. Since the summer Olympic Games are under the scrutiny, we analyse the achievements and medals earned. It is rather fortunate that the Polish Olympic Committee has been gathering such information since the early 20th century Olympic Games (table 3). Taking into account only the number of medals won, the most successful were the Moscow Olympic Games in 1980, with the Polish national team winning as many as 32 .

Presentation of medals awarded to sportsmen and sportswomen during the Olympic Games (1924-2016) (table 4) shows that women are trying to catch up, and in some years they manage to do so. There are two Olympic Games where women won more medals than men: Athens (2004) and Rio de Janeiro (2016). The Olympic Games in Berlin (1936) and London (2012) brought the same number of medals for both genders. Overall, in the analysed period women won in total 62 medals, while men as many as 221 . On one hand this might indicate gender disparity, yet since the period of analyses is almost a century, it also shows the growth of interests and involvement of women in sport, in professional sport in particular (table 4). 
Splitting all the medals earned in the analysed period into classes allows to discuss the value of achievements in each Games in a more aggregate manner, and to see the 'medal power' for each gender (table 4). For each class the 'power' is still higher for medals earned by men. This is not very surprising taking into account the total number of medals won by each gender.

However, as already mentioned, for many years women were not active in many disciplines of sport and their involvement has been growing since the mid-20th century. It has been possible because of social changes, as well as technological and media advancements. They increased interest in many disciplines and in sport in general, starting from passive involvement, like viewing, to the active one.

No doubt passive engagement is more frequent since as many as 29 million Poles watched at least some competitions during the Games, and out of many disciplines volleyball enjoyed the greatest audience. Modern technologies also support viewing the events via the Internet (Pallus, 2016). The most-watched disciplines were men's volleyball, handball, cycling and hammer throw (table 5). This also suggests that the most popular disciplines to watch are male dominated. Unfortunately, there is no information on the audience gender, yet one can suspect that it is male-dominated as well.

\section{Conclusion}

The presented material proves that globalisation has introduced many changes to human activities, including sport. In the last $40-50$ years sport has become an important element of human lives and policy making. Governments of various countries, including Poland, see it as a way to influence their citizens, to promote the country's position in the international arena and to create national pride.

Public governance is well seen in the actions of the Polish authorities which formulate numerous policies to promote sport and encourage individuals to be active. To some degree these are actions related to other areas influenced by sport like health and well-being, but others are simply induced by the membership in the European Union.

Sport is seen as an element of culture and daily routine, even though some analyses show that in many cases it remains passive. Many individuals prefer watching and cheering their sport celebrities instead of actively engaging in physical activity. There is no doubt that such popularity of sport, even when passive, is related to the access to modern, digital technologies. Yet, various policies and programmes are meant to encourage active engagement in sport, but they still require time to deliver results in the future.

The analyses of public spending on sport raise some concerns. First of all, the expenditure incurred is not very generous and there are no equal allocations between disciplines. Not surprisingly, from time to time supporters are informed by the media about problems of national associations with the financ- 
ing of the preparation and trainings of their sportsmen and sportswomen, yet such data is not available yet.

Some modest analyses show a striking gender bias in the Polish professional sport. It can be analysed from various angles, as some sports are gender specific and male-dominated. Some sports might have both male and female sportspersons, yet one of the genders might dominate. Some disciplines make it difficult or unfavourable for women to compete, somehow keeping female interest low.

Modern, digital technologies and their simultaneous nature has been playing an important role in globalisation of sport. Sport, similarly to other areas of life, is influenced particularly by the fast pace of computerisation on a global scale (Gaspareniene et al., 2016). Surely, the Internet and development of technologies play a pivotal role in this process. As mentioned earlier, it helps to popularise and mainstream various disciplines, share information about them, foster interest and active attitudes of supporters. Yet, the available data and analyses prove that a number of inequalities exist. No doubt the contemporary sport depends on modern technologies, including digital ones. Media have become an important player on the market having an impact on development and promotion of some disciplines, as well as influencing public policies related to sport (Burski, 2017, pp. 35-38). The final concern relates to the fact that some gender disparity may be observed in media coverage. As a result, interest in some disciplines is higher when male teams are competing.

Based on this investigation, which gives certain grounds for further academic discussion, initial conclusions can be drawn. First, more analyses of public sport related expenditure and its effectiveness are required to see the overall picture, also in terms of sports discipline and gender. Second, there is an open question on how to ensure more fair allocation of public money to various disciplines. Third question concerns the optimisation of modern technologies to use their potential in promoting sport, in particular the professional one.

\section{References}

Bednarczyk, M., \& Batorski J. (Eds.). (2009). Przedsiębiorczość w zarządzaniu sportem. Kraków: Fundacja dla UJ.

Burski, J. (2017). Globalizacja. In H. Jakubowska, \& P. Nosal (Eds.), Socjologia sportu. Warszawa: PWN.

Cohen, R., \& Kennedy, P. (2007). Global sociology. Basingstoke: Palgrave Macmillan.

Council Recommendation of 26 November 2013 on promoting health-enhancing physical activity across sectors (OJ C 354).

Cynarski, W.J, Kosiewicz, J., \& Obodyński, K. (Eds.). (2012). Kultura fizyczna i sport w zwierciadle nauk spotecznych. Rzeszów: Uniwersytet Rzeszowski.

Dirzyte, A., Rakauskiene, O.G., \& Servetkiene, V.(2017). Evaluation of resilience impact on socio-economic inequality. Entrepreneurship and Sustainability Issues, 4(4). doi:10.9770/jesi.2017.4.4(7). 
Doktór, K. (2005). Zarys socjologii zarządzania sportem. Warszawa: Polska Korporacja Menedżerów Sportu.

Dziubiński, Z., \& Rymarczyk, P. (Eds.). (2010). Kultura fizyczna a globalizacja. Warszawa: AWF, Salezjańska Organizacja Sportowa Rzeczypospolitej Polskiej.

Foks, J. (Ed.). (2006). Unia Europejska i sport: implikacje cztonkostwa Polski $w$ Unii Europejskiej dla polskiego sportu. Warszawa: Polski Instytut Spraw Międzynarodowych.

Gaspareniene, L., Remeikiene, R., Sadeckas, A., \& Ginevicius, R. (2016). Level and sectors of digital shadow economy: the case of Lithuania. Entrepreneurship and Sustainability Issues, 4(2). doi:10.9770/jesi.2016.4.2(6).

Grodecki, M.(2018). Życie po meczu: formy wykorzystania kapitatu spotecznego kibiców pitkarskich $w$ Polsce. Warszawa: UW.

Hannerz, U. (2000). Scenarios for peripheral cultures. In F.J. Lechner, \& J. Boli (Eds.), The globalization reader. Malden: Blackwell Publishing.

Hay, C. (2011). Wpływ globalizacji na państwo. In J. Ravenhill (Ed.), Globalna ekonomia polityczna. Kraków: UJ.

Jakubowska, H, \& Nosal, P. (Eds.). (2017). Socjologia sportu. Warszawa: PWN. Krawczyk, Z. (2000). Sport w zmieniającym się spoteczeństwie. Warszawa: AWF.

Lenartowicz, M., \& Mosz, J. (2018). Stadiony i widowiska: spoteczne przestrzenie sportu. Warszawa: Scholar.

Mamcarczyk, M. (2016). Regionalne zróżnicowanie finansowania infrastruktury sportowej ze środków unijnych w Polsce. In A. Witkowska-Paleń (Ed.), Polityka spoteczna w dziataniu: wybrane zagadnienia. Lublin: KUL.

Mamcarczyk, M. (2018). Globalizacja a sport. In B. Szopa, \& E. Ślęzak (Eds.), Spoteczne aspekty globalizacji. Warszawa: PWE.

Ministry of Foreign Affairs. (2011). Programme of the Polish presidency of the Council of the European Union. Retrieved 10.03.2019 from https: / /www.umww.pl.

Ministry of Sport and Tourism. (2015). 2020 Sport development programme. Retrieved 14.02.2020 from https://bip.msit.gov.pl.

Ministry of Sport and Tourism. (2019). Program Otwarte Strefy Aktywności 2019 rozstrzygnięty. Retrieved 28.12.2019 from https://www.gov.pl.

Nowocień, J. (2001). Sport i olimpizm w systemie dydaktyczno-wychowawczym wspótczesnej szkoty. Warszawa: AWF.

Nowocień, J., \& Chetmecki, J. (Eds.). (2010). Spoteczno-edukacyjne oblicza wspótczesnego sportu i olimpizmu: aktywność fizyczna dzieci, mtodzieży i dorostych na przetomie XX i XXI wieku. Warszawa: AWF.

Pallus, P. (2016). Prawie $29 \mathrm{mln}$ Polaków obejrzato chociaż fragment transmisji z igrzysk. Retrieved 14.03.2019 from https: / /businessinsider.com.pl.

Pastwa, M. (2000). Zarządzanie finansami instytucji sportowo-rekreacyjnych. Warszawa: Polska Korporacja Menedżerów Sportu.

Pawlak, Z., \& Smoleń, A. (2007). Zarządzanie finansami spótek kapitatowych w sporcie kwalifikowanym z perspektywy rachunkowości finansowej i zarządczej. Warszawa: AWF. 
Polish Olympic Committee. (2019). Retrieved 01.03.2019 from https://www. olimpijski.pl.

Polus, A. (Ed.). (2009). Sport w stosunkach międzynarodowych. Toruń: Adam Marszałek.

PWN. (2019). Stownik języka polskiego. Retrieved 14.03.2019 from http://sjp. pwn.pl.

Rischka-Słowik, B. (2014). Konstytucja sportu w Unii Europejskiej. Warszawa: C.H. Beck.

Roemer, J.E. (2011). Equality: its justification, nature, and domain. In B. Nolan, W. Salverda, \& T.M. Smeeding (Eds.), The Oxford handbook of economic inequality. Oxford: Oxford University Press. doi:10.1093/ oxfordhb/9780199606061.001.0001.

Rozporządzenie Rady Ministrów z dnia 4 sierpnia 2016 r. w sprawie Narodowego Programu Zdrowia na lata 2016-2020 [Regulation of the Council of Ministers of 4 August 2016 regarding the National Health Program for 2016-2020] (Dz.U. 2016 poz. 1492) (Poland).

Sporek, T. (2007). Sponsoring sportu w warunkach globalizacji: dylematy i wyzwania. Warszawa: Difin.

Sznajder, A. (2008). Marketing sportu. Warszawa: PWE.

Sznajder, A. (2017). Sport jako biznes w czasach globalizacji. Warszawa: PWE.

Ślęzak, E. (2018). Globalizacja i jej oblicza. In B. Szopa, \& E. Ślęzak (Eds.), Spoteczne aspekty globalizacji. Warszawa: PWE.

Treaty of Lisbon amending the Treaty on European Union and the Treaty establishing the European Community (OJ C 306).

Treaty on the functioning of the European Union: consolidated version (OJ C 326).

Uchwała Rady Ministrów nr 90/2007 z dnia 15 maja 2007 r. w sprawie Narodowego Programu Zdrowia na lata 2007-2015 [Resolution of the Council of Ministers of 15 May 2007 regarding the National Health Program for 2007-2015].

Ustawa z dnia 25 czerwca 2010 r. o sporcie [Act of 25 June 2010 on sport] (Dz.U. $2010 \mathrm{nr} 127$ poz. 857) (Poland).

Waśkowski, Z. \& Sojkin, B. (Eds.). (2011). Zarządzanie polskim sportem w gospodarce rynkowej. Poznań: UE w Poznaniu.

Wicker, P., Breuer, C., \& Pawlowski, T. (2009). Promoting sport for all to age-specific target groups: the impact of sport infrastructure. European Sport Management Quarterly, 9(2). doi:10.1080/16184740802571377.

Załączniki nr 2 do Ustaw Budżetowych na lata 2009-2019 [Annexes 2 to the Budget Acts for the years 2009-2019]. Retrieved 10.03.2019 from http://orka.sejm.gov.pl.

Żyśko, J. (2008). Zmiany we wspótczesnych systemach zarządzania sportem wyczynowym w wybranych krajach europejskich. Warszawa: AWF. 


\section{Acknowledgements}

Author contributions: authors have given an approval to the final version of the article. Authors contributed to this work equally.

Funding: this research was funded by the Cracow University of Economics, Faculty of Finance and Law sources.

Note: the results of this study were presented at 10th International Conference on Applied Economics Contemporary Issues in Economy (June 27-28, 2019, Torun, Poland). 


\section{Appendix}

Table 1.

Budget expenditure on physical culture between 2009 and 2019 (in PLN thousands)

\begin{tabular}{lccc}
\hline Year & Total budgeted amount & Total budget expenditure & $\begin{array}{c}\text { Share of expenditure on physical culture in to- } \\
\text { tal budget expenditure (in \%) }\end{array}$ \\
\hline 2009 & 289430 & 321221112 & 0.09 \\
2010 & 483627 & 301220817 & 0.16 \\
2011 & 985683 & 313344394 & 0.31 \\
2012 & 538055 & 328765688 & 0.16 \\
2013 & 258478 & 327294440 & 0.08 \\
2014 & 251674 & 325287369 & 0.08 \\
2015 & 265445 & 343277818 & 0.08 \\
2016 & 290039 & 368548526 & 0.08 \\
2017 & 274814 & 384773502 & 0.07 \\
2018 & 258519 & 397179405 & 0.07 \\
2019 & 258313 & 416111586 & 0.06 \\
\hline
\end{tabular}

Notes:

Budget expenditure is presented in accordance with section 926 Physical culture and sport (for 20092010) and Physical culture (for 2011-2019).

Source: Own preparation based on Annexes 2 to the Budget Acts (2009-2019).

Table 2.

Actual expenditure on professional sport between 2009 and 2018 (in PLN thousands)

\begin{tabular}{lcc}
\hline Year & Professional sport expenditure & Share in total budget expenditure (in \%) \\
\hline 2009 & 339452 & 0.11 \\
2010 & 317284 & 0.10 \\
2011 & 299895 & 0.09 \\
2012 & 310683 & 0.09 \\
2013 & 307311 & 0.09 \\
2014 & 317819 & 0.10 \\
2015 & 343711 & 0.10 \\
2016 & 377631 & 0.10 \\
2017 & 393210 & 0.10 \\
2018 & 398528 & 0.10 \\
\hline
\end{tabular}

Sources: Own preparation based on unpublished data obtained from the Ministry of Sport and Tourism's Economic and Financial Department. 
Table 3.

Medals earned at the Summer Olympic Games in 1924-2016

\begin{tabular}{llcccc}
\hline Year & \multicolumn{1}{c}{ Place } & Gold & Silver & Bronze & Sum \\
\hline 1924 & Paris & - & 1 & 1 & 2 \\
1928 & Amsterdam & 1 & 1 & 3 & 5 \\
1932 & Los Angeles & 2 & 1 & 4 & 7 \\
1936 & Berlin & - & 3 & 3 & 6 \\
1948 & London & - & - & 1 & 1 \\
1952 & Helsinki & 1 & 2 & 1 & 4 \\
1956 & Melbourne & 1 & 4 & 4 & 9 \\
1960 & Rome & 4 & 6 & 11 & 21 \\
1964 & Tokyo & 7 & 6 & 10 & 23 \\
1968 & Mexico & 5 & 2 & 11 & 18 \\
1972 & Munich & 7 & 5 & 9 & 21 \\
1976 & Montreal & 7 & 6 & 13 & 26 \\
1980 & Moscow & 3 & 14 & - & 32 \\
1984 & Los Angeles & - & - & 9 & 16 \\
1988 & Seoul & 2 & 5 & 10 & 19 \\
1992 & Barcelona & 3 & 6 & 5 & 17 \\
1996 & Atlanta & 7 & 5 & 3 & 14 \\
2000 & Sydney & 6 & 5 & 5 & 10 \\
2004 & Athens & 3 & 2 & 2 & 11 \\
2008 & Beijing & 4 & 5 & 6 & 283 \\
2012 & London & 3 & 1 & 132 & \\
2016 & Rio & 2 & 3 & & 11 \\
& Sum & 68 & & 5 & \\
\hline
\end{tabular}

Source: Own preparation based on the Polish Olympic Committee (2019). 
Table 4.

Medals earned at the Summer Olympic Games by gender in 1924-2016

\begin{tabular}{|c|c|c|c|c|c|c|c|c|c|}
\hline \multirow{2}{*}{ Year } & \multirow{2}{*}{ Place } & \multicolumn{2}{|c|}{ Gold } & \multicolumn{2}{|c|}{ Silver } & \multicolumn{2}{|c|}{ Bronze } & \multicolumn{2}{|c|}{ Sum } \\
\hline & & woman & men & woman & men & woman & men & woman & men \\
\hline 1924 & Paris & 0 & 0 & 0 & 1 & 0 & 1 & 0 & 2 \\
\hline 1928 & Amsterdam & 1 & 0 & 0 & 1 & 0 & 3 & 1 & 4 \\
\hline 1932 & Los Angeles & 1 & 1 & 0 & 1 & 2 & 2 & 3 & 4 \\
\hline 1936 & Berlin & 0 & 0 & 2 & 1 & 1 & 2 & 3 & 3 \\
\hline 1948 & London & 0 & 0 & 0 & 0 & 0 & 1 & 0 & 1 \\
\hline 1952 & Helsinki & 0 & 1 & 0 & 2 & 0 & 1 & 0 & 4 \\
\hline 1956 & Melbourne & 1 & 0 & 0 & 4 & 1 & 3 & 2 & 7 \\
\hline 1960 & Rome & 0 & 4 & 2 & 4 & 1 & 10 & 3 & 18 \\
\hline 1964 & Tokyo & 1 & 6 & 3 & 3 & 2 & 8 & 6 & 17 \\
\hline 1968 & Mexico & 1 & 4 & 0 & 2 & 2 & 9 & 3 & 15 \\
\hline 1972 & Munich & 0 & 7 & 1 & 4 & 1 & 8 & 2 & 19 \\
\hline 1976 & Montreal & 1 & 6 & 0 & 6 & 0 & 13 & 1 & 25 \\
\hline 1980 & Moscow & 0 & 3 & 2 & 12 & 3 & 12 & 5 & 27 \\
\hline 1988 & Seoul & 0 & 2 & 0 & 5 & 0 & 9 & 0 & 16 \\
\hline 1992 & Barcelona & 0 & 3 & 0 & 6 & 2 & 8 & 2 & 17 \\
\hline 1996 & Atlanta & 1 & 6 & 0 & 5 & 2 & 3 & 3 & 14 \\
\hline 2000 & Sydney & 2 & 4 & 2 & 3 & 1 & 2 & 5 & 9 \\
\hline 2004 & Athens & 1 & 2 & 2 & 0 & 4 & 1 & 7 & 3 \\
\hline 2008 & Beijing & 0 & 4 & 2 & 3 & 1 & 1 & 3 & 8 \\
\hline 2012 & London & 1 & 2 & 1 & 0 & 3 & 3 & 5 & 5 \\
\hline 2016 & Rio & 2 & 0 & 2 & 1 & 4 & 2 & 8 & 3 \\
\hline Sum & & 13 & 55 & 19 & 64 & 30 & 102 & 62 & 221 \\
\hline
\end{tabular}

Source: Own preparation based on the Polish Olympic Committee (2019).

Table 5.

Media coverage of sport during the Rio Olympic Games and its audience

\begin{tabular}{lccc}
\hline \multicolumn{1}{c}{ Discipline } & Date & Average audience & Average market share (in \%) \\
\hline volleyball men (Poland-Argentina) & 2016.08 .11 & 4474523 & 31.92 \\
volleyball (Poland-USA) & 2016.08 .17 & 4348914 & 34.35 \\
volleyball men (Poland-Russia) & 2016.08 .13 & 4073523 & 32.50 \\
hammer throw women & 2016.08 .15 & 3591976 & 34.24 \\
handball men (Poland-Germany) & 2016.08 .21 & 3473513 & 30.37 \\
handball men (Poland-Brazil) & 2016.08 .07 & 3397897 & 26.84 \\
volleyball men (Poland-Kuba) & 2016.08 .15 & 3273531 & 27.80 \\
cycling women & 2016.08 .07 & 2869908 & 20.03 \\
cycling men & 2016.08 .06 & 2824872 & 23.77 \\
handball men (Poland-Egypt) & 2016.08 .11 & 2801980 & 31.22 \\
\hline
\end{tabular}

Source: Own preparation based on Pallus (2016). 
Scheme 1 .

Typology of sport (criterion: purpose of practicing and the characteristics of sportspersons)

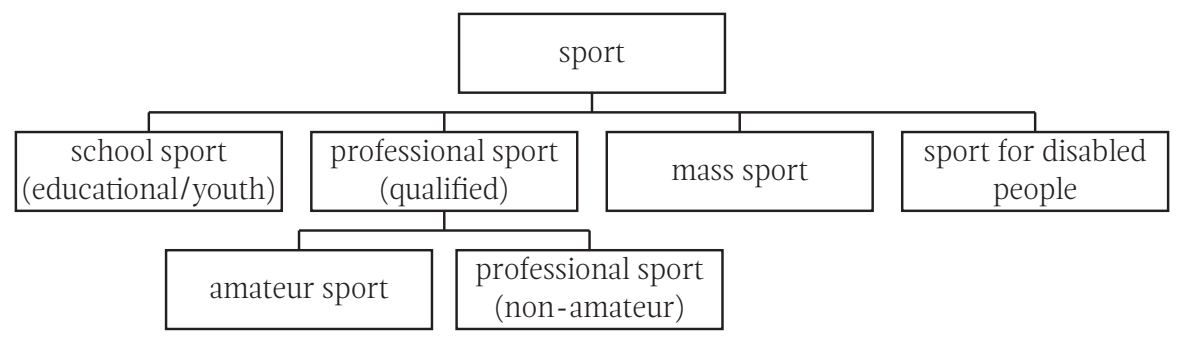

Source: Own preparation based on Krawczyk (2000, p. 142), Mamcarczyk (2018, p. 145), Sznajder (2008, p. 15). 
